\title{
ANALISIS YURIDIS TERHADAP SUNTIK MATI (EUTHANASIA) DITINJAU DARI PERSPEKTIF HUKUM PIDANA
}

Oleh :

\author{
1. Harry Murty ${ }^{1}$ \\ 2. Ariella Gitta Sari ${ }^{2}$ \\ 3. Irham Rahman ${ }^{3}$
}

\begin{abstract}
Abstraksi
Perkembangan zaman mempengaruhi teknologi dalam bidang kesehatan dan memberikan pengaruh terhadap pemikiran tentang konsep kematian. Permohonan akan permintaan mati dikarenakan upaya untuk bertahan hidup tidak berhasil. Situasi yang seperti inilah menyebabkan suntik mati (euthanasia) dilakukan. Euthanasia dilakukan di Indonesia karena adanya suatu dan permohonan tersebut membuka peluang untuk menerapkan euthanasia di Indonesia. Kebijakan untuk memberlakukan euthanasia di Indonesia mendapatkan respon pro dan kontra di masyarakat. Oleh sebab itu tujuan penelitian yaitu untuk mengetahui pengaturan tentang suntik mati (euthanasia) dalam prespektif hukum pidana di Indonesia dan untuk mengetahui kebijakan menerapkan euthanasia di Indonesia dari sisi hukum pidana (KUHP). Penelitian ini menggunakan metode penelitian hukum yuridis normatif yang menggunakan pendekatan The Statute Approach dan pendekatan analisis konsep hukum. Hasil dari penelitian ini adalah bahwa euthanasia di Indonesia belum memiliki regulasi yang jelas namun ditemukan beberapa pengaturan hukum yang secara tidak langsung memiliki pengaturan tentang euthanasia, antara lain UUDNRI 1945, dan Pasal 344 KUHP, selain itu dari analisis penelitian ini menunjukan bahwa apabila dikaji dari KUHP akan kebijakan untuk menerapkan euthanasia di Indonesia tidaklah mungkin untuk diterapkan karena KUHP memandang euthanasia sebagai suatu tindak pembunuhan.
\end{abstract}

Kata Kunci : Kematian, Hukum Pidana, Euthanasia.

\section{Latar Belakang}

Perkembangan zaman membuat perubahan yang sangat besar terhadap ilmu pengetahuan, termasuk pada bidang teknologi dalam kesehatan. Kemajuan teknologi dalam bidang ilmu kesehatan membawa pengaruh yang besar pada

\footnotetext{
${ }^{1}$ Dosen Fakultas Hukum Universitas Kadiri, email : harry_murty@unik-kediri.ac.id

${ }^{2}$ Dosen Fakultas Hukum Universitas Kadiri, email : ariellagitta@unik-kediri.ac.id

${ }^{3}$ Dosen Fakultas Hukum Universitas Kadiri, email : irhamrahman@unik-kediri.ac.id
} 
manusia terhadap harapan untuk hidup yang lebih baik dari sebelumnya. ${ }^{4} \mathrm{Hal}$ ini bisa dilihat bahwa kemajuan teknologi memberikan pengaruh yang baik atau positif. Namun terlepas dari kemajuan teknologi yang berpengaruh positif, bagi sebagian orang beranggapan bahwa kemajuan tersebut mengakibatkan pengaruh yang negatif pula. Pengaruh negatif yang dimaksud yaitu akan pemikiranmanusia terhadap suatu kematian.

Pengaruh negatif dari kemajuan teknologi dalam ilmu kesehatan mengakibatkan keluarga dari seorang pasien atau pasien sendiri mengajukan permohonan kepada tenaga medis atau dokter untuk mempercepat kematian bagi seorang pasien guna menghilangkan rasa sakit sehingga pasien bisa beristirahat dengan tenang. Adapun permohonan untuk mati dikarenakan tidak adanya persediaan obat yang dapat menyembuhkan, mengantisipasi atau mengurangi penyakit maupun rasa sakit yang dirasakan oleh pasien. ${ }^{5}$, tenaga medis dan dokter yang sudah tak mampu untuk menangani, dan tidak adanya kemampuan untuk menanggung biaya perawatan bagi pasien maupun keluarganya. Hal-hal tersebutlah yang melatarbelakangi dilakukannya suntik mati atau euthanasia.

Masyarakat mulai memperbincangkan keberadaan euthanasia di Indonesia yang muncul akibat dari permohonan pasien maupun keluarga pasien untuk melakukan euthanasia. Adapun permohonan euthanasia yang telah diajukan di Indonesia antara lain diawali dengan kasus permohonan euthanasia terhadap Agian Isna Nauli yang dimohonkan oleh Panca Satria Hassan Kusuma ke Pengadilan Negeri Jakarta Pusat pada tahun 2004, kasus permohonan euthanasia terhadap Siti Zulaeha yang di mohonkan oleh Rudi Hartono ke Pengadilan Negeri Jakarta Pusat, kasus permohonan pengujian undang-undang (pasal 344 KUHP) ke Mahkamah Agung dengan nomor perkara 55/PUU-XII/2014 yang dimohonkan oleh Ignatitus Ryan Turniwa, dan kasus permohonan euthanasia yang terakhir dimohonkan oleh Berlin Sialahi.

Alexandra Indriyanti, 2008, Etika dan Hukum Kesehatan, Pustaka Book Publisher, Yogyakarta, hlm. 67.

Hadi, S. 2012, Euthanasia Dalam Perspektif Hukum Pidana dan Etika Kedokteran. Progresif, 4(1), hlm.2. 
Permohonan-permohonan yang diajukan guna dilakukannya suntik mati atau euthanasia di Indonesia telah membuka peluang euthanasia untk diterapkan di Indonesia. Namun kebijakan untuk menerapkan euthanasia di Indonesia telah menimbulkan pertentangan (pro dan kontra) di masyarakat. Sebagian masyarakat beranggapan bahwa euthanasia perlu untuk di terapkan di Indonesia mengingat bahwa manusia mempunyai hak untuk menentukan nasib sendiri memandang disatu sisi, euthanasia perlu untuk diterapkan dengan pertimbangan alasan kemanusiaan dan mengingat bahwa manusia memiliki hak untuk the right of selfdetermination atau menentukan nasibnya sendiri termasuk dengan memilik hak untuk mati yang kedudukannya sejajar dengan hak hidup. Sedangkan dilain sisi sebagian masyarakat memandang bahwa euthanasia merupakan tindakan pembunuhan terhadap nyawa secara terselubung yang dikategorikan sebagai tindakan yang melanggar hukum dan juga sebagai perbuatan yang melanggar hak untuk hidup atau right to life serta dikawatirkan bahwa penerapan euthanasia bisa digunakan sebagai salah satu cara untuk menekan jumlah penduduk yang setiap hari jumlahnya kian bertambah.

Secara umum perdebatan tentang pro dan kontra terkait euthnasia dalam masyarakat dapat dibedakan menjadi dua bagian, antara lain sebagai berikut:

a. kelompok pertama yang dengan tegas menyatakan tidak setuju dengan keberadaan euthanasia di Indonesia dengan alasan bahwa euthanasia merupakan tindakan bunuh diri karena menyerah akan hidup yang pada hakekatnya tindakan tersebut dilarang oleh seluruh agama, dan euthanasia dianggap sebagai tindakan pembunuhan secara terselubung yang dengan tegas pula merupakan suatu tindakan melanggar hukum.

b. kelompok kedua yaitu yang dengan tegas menyatakan bahwa setuju dengan diterapkannya euthanasia, alasannya karena euthanasia merupakan hak asasi setiap individu/manusia untuk menentukan pilihan dalam hidupnya termasuk memilih hak untuk hidup maupun mati yang keduanya memiliki kedudukan yang sejajar. Dan yang memperkuat alasan kelompok ini yaitu karena tindakan euthanasia merupakan permohonan atau keinginan dari pemohon euthanasia sendiri. 
Mengingat bahwa euthanasia merupakan persoalan yang menyangkut kepentingan banyak orang sehingga terkait dengan penerapan eutahansia di Indonesia sendiri perlu diketahui tentang bagaimana regulasi euthanasia menurut hukum positif dan bagaimana kebijakan untuk menerapkan euthanasia di Indonesia dipandang dari sisi hukum pidana (KUHP). Berdasarkan permasalahan yang diangkat dalam penelitian ini maka penulis mengambil judul Analisis Yuridis Terhadap Suntik Mati (Euthanasia) Ditinjau Dari Perspektif Hukum Pidana.

\section{Rumusan Masalah}

Berdasarkan pada latar belakang yang dikemukakan sebelumnya maka rumusan masalah yang dapat diambil dalam penelitian ini yaitu :

2.1 Bagaimana regulasi tentang suntik mati (euthanasia) dalam prespektif hukum pidana di Indonesia?

2.2 Bagaimana kebijakan untuk menerapkan suntik mati (euthanasia) di Indonesia dari sisi hukum pidana (KUHP) ?

\section{Tujuan Penelitian}

Adapun tujuan yang hendak dicapai dalam penelitian ini adalah sebagai berikut :

3.1 Untuk mengetahui regulasi tentang suntik mati (euthanasia) dalam prespektif hukum pidana di Indonesia.

3.2 Untuk mengetahui kebijakan untuk menerapkan suntik mati (euthanasia) di Indonesia dari sisi hukum pidana (KUHP).

\section{Manfaat Penelitian}

Hasil Penelitian ini, secara teoritis maupun praktis diharapkan dapat memberikan manfaat bagi akademisi atau peneliti hukum untuk mengembangkan ilmu pengetahuan dibidang hukum pidana khususnya kebijakan untuk menerapkan suntik mati (euthanasia) di Indonesia. 


\section{Metode Penelitian}

Penelitian ini menggunakan penelitian hukum yuridis normatif yang mana penelitian hukum ini dilakukan dengan cara meneliti bahan pustaka atau data sekunder. ${ }^{6}$ sedangkan penelitian ini menggunakan jenis pendekatan peraturan perundang-undangan atau The Statute Approach dan pendekatan analisis konsep hukum atau Analitical \& Conseptual Approach.

Penelitian ini menggunakan bahan hukum atau bahan pustaka, adapun bahan hukum atau bahan pustaka yang digunakan meliputi :

1. Terdiri dari bahan hukum primer yang meliputi : UUD 1945, Kode Etik Kedokteran (KODEKI), Kitab Undang-Undang Hukum Pidana (KUHP), Undang-Undang No. 29 Tahun 2004 tentang Praktik Kedokteran, dan Undang-Undang No. 36 Tahun 2009 tentang Kesehatan.

2. Bahan hukum sekunder yang digunakan meliputi : bahan hukum sekunder merupakan penjelas dari bahan hukun primer, bahan hukum sekunder dalam penelitian ini meliputi hasil dari penelirtian hukum, literatur yang berkaitan dengan obyek penelitian ini, dan hasil karya ilmiah.

3. Bahan hukum tersier : merupakan bahan hukum yang akan memberikan penjelasan dan petunjuk yang berkaitan dengan bahan hukum primer dan bahan hukum sekunder seperti ensiklopedia hukum, kamus, dan lain sebagainya.

Teknik pengumpulan data dalam penelitian ini dengan melakukan langkahlangkah yakni mengumpulkan bahan hukum, mempelajari atau menganalisa literatur-literatur yang memiliki kaitan dengan obyek permasalahan dalam penelitian serta mengutip beberapa pendapat maupun pernyataan yang mendukung guna menjawab permasalahan dalam penelitian ini dan kemudian secara sistematis disusun sebagai landasan hukum guna memberi jawaban dari permasalan.

Dalam menganalisis, penelitian ini menggunakan teknik deskriptif dan teknik sistematisasi. Teknik deskriptif merupakan tekni yang menguraikan posisi atau

Soerjono Soekanto dan Sri Mamudji, 2006, Penelitian Hukum Normatif Suatu Tinjauan Singkat, PT. Raja Grafindo Persada, Jakarta h.13. 
kondisi secara apa adanya dari porsi-porsi hukum maupun di luar hukum. Sedangkan teknik sistematisasi yakni teknik yang mencari keterkaitan suatu rumusan dalam proposisi hukum antara regulasi atau peraturan hukum yang sebanding maupun antara peraturan perundang-undangan yang tidak sebanding atau sederajat.

\section{Pembahasan}

\subsection{Regulasi Tentang Suntik Mati (Euthanasia) Dalam Prespektif Hukum Pidana Di Indonesia}

Euthanasia atau suntik mati berasal dari terjemahan bahasa Yunani dari kata Euthanathos yang mana secara terminologi kata euthanasia berasal dari artian tanpa penderitaan yang berasal dari kata "eu", dan "tanathos" yang memiliki pengertian kematian atau mati. Sehingga euthanasia memiliki arti sebagai mati dengan tanpa adanya rasa penderitaan yang dirasakan oleh pasien atau mati dengan baik. "Euthanasia is the intentional killing by act or omission of a dependent human being for his or her alleged benefit. (The key word here is 'intentional'. If death is not intended, it is not an act of euthanasia)." 8

Pada masa kini, kususnya di negara yang memperbolehkan penerapan euthanasia, euthanasia sendiri mengalami perdebatan yang sangat panjang dan rumit. Berbagai negara tidak dapat memberikan suara bulat atau kepastian antara boleh diterapkan atau tidaknya euthanasia bagi seseorang dan masala tersebut telah masuk ke Indonesia. Euthanasia menjadi perdebatan yang membelah dua golongan yakni antara kubu ya pro dengan penerapan euthanasia maupun kubu yang kontra. Masing-masing golongan mempunyai pendapat yang menguatkan alasan tentang euthanasia. Pada prinsipnya, setiap individu atau manusia memiliki hak asasi yang bersifat fundamental dimana setiap manusia memiliki kebebasan untuk memilih dan mengambil keputusan,

Soekidjo Notoatmodjo, 2010, Etika \& Hukum Kesehatan, Rineka Cipta, Jakarta, h.144.

Anonim, "Euthanasia Definitions", URL : http://www.euthanasia.com/definitions.html. Diakses pada 19 November 2017 
dan setiap orang berhak untuk mempertahankan hidup serta berhak hidup hal ini juga di atur dalam UUD 1945.

Hak tersebut juga dimiliki oleh setiap pasien, didalam hak hidup juga sejajar pula hak untuk memilih mati yang seringkali disebut dengan istilah euthanasia. Banyak ahli yang telah membicaran permasalahan euthanasia, namun euthanasia tetap menjadi sebuah perdebatan yang melelahkan lagi panjang terutama apabila terjadi kasus-kasus yang muncul ke permukaan publik. Banyak sekali faktor-faktor yang menjadi penyebab dilakukannya euthanasia terhadap pasien, faktor-faktor tersebut dilihat dari berbagai sudut pandang seperti sudut pandang moral, agama, medis, serta sudut pandang hukum sendiri yang belum menyatakan kata sepakat dalam menghadapi permohonan pasien yang meminta untuk mati demi menghilangkan rasa sakit atau penderitaan yang dialami. Kondisi yang seperti ini menimbulkan para dokter dilemaapakah memiliki hak hukum untuk mengakiri hidup seorang pasien meskipun itu merupakan permohonan sendiri dari pasien atau keluarga pasien karena tugas dokter bukan untuk mengakiri nyawa manusia melainkan tugasnya untuk berupaya menyembuhkan penyakit yang diderita oleh pasien. Dalam situasi tersebut dokter akan mengalami konflik batin meskipun guna dari dilakukannya euthanasia sendiri untuk mengakhiri penderitaan yang selama ini telah dialami pasien secara berkepanjangan.

Euthanasia menurut ikatan dokter Belanda, merupakan suatu tindakan yang dengan sengaja tidak melakukan upaya untuk memperpanjang hidup seorang pasien atau sebaliknya dengan sengaja melakukan tindakan untuk memperpendek hidup pasien atau mengakhiri hidup pasien, dan tindakan tersebut dilakukan karena permohonan pasien sendiri. ${ }^{9}$ Di dalam KODEKI atau Kode Etik Kedokteran Indonesia, penggunaan euthanasia diartikan menjadi tiga arti, yakni :

a. Berpindah dari alam dunia ke alam baka dengan aman dan tenang tanpa mengalami rasa sakit, dan untuk beriman kepada Tuhan dibibir.

Alexandra Indriyanti, op.cit, h.80. 
b. Diringankan penderitaan seseorang dengan memberikan obat penenang ketika telah tiba masa-masa kehidupannya berakhir.

c. Mengakhiri rasa sakit atau penderitaan dari seseorang yang mengalami sakit, dengan sengaja atas permohonan dari pasien atau keluarganya sendiri. $^{10}$

Berdasarkan dari uraian-uraian yang telah disampaikan sebelumnya maka bisa disimpulkan bahwa euthanasia merupakan suatu tindakan yang dilakukan secara sengaja (kesengajaan) untuk tidak melakukan atau melakukan sesuatu (kelalaian) kepada pasien demi kepentingan dari pasien sendiri, yang mana tindakan tersebut dilakukan tanpa adanya rasa sakit dan bertujuan untuk mengakhiri penderitaan dengan cara kematian atau menghilangkan nyawa.

Sebelum menjelaskan macam-macam euthanasia, terlebih dahulu dijelaskan tentang penggolongan dalam kematian menurut Abdul Mun'im Idries, yang mana digolongkan menjadi tiga bagian yakni :

1. Kematian Somatic Death atau mati klinis

Merupakan kematian yang terjadi dikarenakan adanya suatu gangguan pada tiga sistem utama dalam tubuh manusia, meliputi sitem kardiovaskular, sitem pernapasan, dan sitem syaraf, yang mana sistem-sistem tersebut memiliki sifat menetap. Didalam fase kematian somatic ini diperoleh dengan tidak didapatinya tanda-tanda keehidupan manusia dimana hilangnya detak jantung, suhu badan yang menurun, tidak adanya gerakan pernapasan, dan hilangnya pergerakan listrik otak pada rekaman EEG.

2. Mati semu atau mati suri (suspended animation, apparent death)

Merupakan suatu situasi yang memiliki kemiripan dengan kematian somatik, akan tetapi kematian ini menunjukan bahwa adanya sifat sementara pada gangguan tiga sistem utama dalam tubuh manusia. Mati semu atau mati suri ini bisa terjadi pada beberapa situasi seperti terkena aliran listri, kasus tenggelam, dan situasi keracunan.

Chisdiono M.Achadiat, 2007, Dinamika Etika dan Hukum Kedokteran Dalam Tantangan Zaman, Buku Kedokteran EGC, Jakarta, h.181. 
3. Kematian Biologik atau kematian molekuler/ kematian selular (biological death)

4. Merupakan keadaan dimana ditandai dengan matinya sel sehingga menyebabkan tidak berfungsinya jaringan atau organ dalam tubuh manusia.

Ilmu pengetahuan juga menggolongkan kematian berdasarkan dengan cara terjadinya, antara lain sebagai berikut :

1. Orthothanasia, yaitu proses alamiah yang menyebabkan suatu kematian pada manusia;

2. Dysthanasia, merupakan kematian yang terjadi secara tidak normal atau tidak wajar;

3. Euthanasia, merupakan kematian yang pasti terjadi dengan tidak adanya pertolongan dari dokter maupun dengan adanya pertolongan.

Euthanasia diklasifikasikan dalam beberapa golongan antara lain sebagai berikut: (a) voluntary euthanasia, kondisi dimana jika yang membuat keputusan adalah orang yang sakit, (b) involuntary euthanasia, kondisi dimana yang membuat keputusan untuk dilakukannya euthanasia adalah orang lain, misalnya seperi pihak keluarga atau keputusan dokter sendiri karena pasien mengalami koma medis yang kemungkinan untuk bangun sangat tipis.

Jika diuraikan lagi, pengertian euthanasia yakni suatu tindakan untuk mempermudah kematian bagi seseorang dengan tanpa merasakan penderitaan atau sakit, karena kasih sayang kepada si penderita dengan tujuan menghilangkan penderitaannya, yang mana tindakan tersebut biasanya dilakukan oleh kalangan tenaga medis atau dokter dengan cara positif maupun negatif, oleh sebab itu Euthanasia dapat dibedakan menjadi beberapa jenis. Euthanasia dapat digolongkan lagi menurut dari cara pelaksanaannya menjadi dua bagian yaitu euthanasia aktif dan euthanasia pasif. Euthanasia aktif ialah suatu tindakan yang dengan sengaja melakukan euthanasia secara medis yang dilakukan oleh seorang tenaga kesehatan atau dokter melalui intervensi aktif dengan tujuan agar manusia (pasien) mengalami kematian. Pengelompokan 
euthansia masuk klarifikasi aktif atau pasif didasarkan dari cara euthanasia itu dilakukan.

Kartono Muhammad berpendapat bahwa Euthanasia aktif ialah suatu tindakan yang mempercepat proses kematian pada manusia, yang tindakan tersebut bisa dilakukan dengan melepaskan alat-alat bantuan medis seperti melepas alat pemacu jantung, saluran asam, bahkan dengan sengaja memberikan suntikkan, dan lain sebagainya. Bahkan tindakan tersebut dilakukan meskipun pasien menunjukkan masih memiliki harapan untuk hidup berdasarkan pengalaman dan ukuran, dengan kata lain pasien masih mempunyai tanda-tanda kehidupan.

Sedangkan Euthansaia pasif memiliki artian bahwa dilakukannya tindakan euthanasia merupakan permohonan maupun tidak atas permohonan pasien. Yang mana tindakan tersebut dilakukan dengan sengaja oleh tenaga medis atau dokter dengan tidak memberikan alat bantuan medis guna memperpanjang hidup pasien (tidak memberikan perawatan yang optimal dalam fase terakhir). Dalam Euthanasia aktif juga masih dibedakan lagi menjadi euthanasia aktif langsung dan euthanasia aktif tidak langsung. Euthanasia aktif langsung atau mercy killing ialah merupakan tindakan yang yang dilakukan secara sitematis dan sangat diperhitungkan langkahnya untuk menghilangkan nyawa pasien, sedangkan eutanasia aktif yang tidak langsung ialah suati tindakan yang dilakukan untuk meringankan rasa sakit atau penderitaan pasien, namun dengan adanya tindakan tersebut diketahui akan menyebabkan pendeknya usia pasien bahwa menghilangkan nyawa pasien. Euthanasia aktif dengan tegas dapat langsung digolongkan kedalam tindakan malpraktek medis yang langsung dapat dimasukkan dalam golongan malpraktek medis yang disengaja atau bisa disebut juga dengan malpraktek medis Kriminal.

Dinyatakan atau disebut dengan criminal malpractic atau malpraktek kriminal jika unsur aduan pidana terpenuhi dalam tindakan tersebut. Tindakan yang dapat dimasukkan dalam kriminal malpraktek yaitu negligence atau kelalaian, recklessness atau kecerobohan, dan intentional atau kesengajaan. 
Contoh dari perbuatan kriminal malpraktek yang memiliki sifat sengaja yaitu sebagai berikut $:^{11}$

1. Melakukan tindakan Arbortus Provocatus tanpa memenuhi suatu unsur hukum.

2. Menerbitkan suatu surat edaran yang tidak memiliki kebenaran didalamnya.

3. Membocorkan indentitas atau rahasia pasien tanpa adanya memenuhi unsur hukum atau tanpa ijin pasien dan

4. Melakukan tindakan Euthanasia (volunter, involunter, aktif maupun pasif)

Suatu tindakan bisa digolongkan sebagai kriminal malpraktek jika memenuhi rumusan delik dalam pidana, anta lain : perbuatan tersebut harus tidak sesuai dengan norma hukum maupun masyarakat, perbuatan tersebut dilakukan dengan adanya kesengajaan, kelalaian , atau kecerobohan hinggal menyebabkan hilangnya nyawa seseorang. Tenaga kesehatan dapat melakukan suatu tindakan kelalaian dalam menjalankan tugasnya, diantara lain diatur dalam hukum pidana atau KUHP : Pasal 531, 361, 360, 359, 351, 349, 348, $347,344,322,304,299,294$ ayat (2), 267, 263. ${ }^{12}$

Malpraktek medis menurut pendapat J. Guwandi, dapat diklasifikasikan menjadi dua macam, antara lain :

a. tindakan tersebut dengan sengaja dilakukan,padahal tindakan tersebut telah dilarang oleh peraturan yang berlaku atau dolus. Dalam kata lain malpraktik merupakan suatu tindakan buruk yang dilakukan dengan sengaja, contohnya seperti melakukan abortus dengan sengaja tanpa adanya indikasi medis, memberikan surat keterangan yang tidak benar, melakukan tindakan euthanasia, dan lain-lain.

b. tindakan yang dilakukan tanpa adanya kesengajaan melainkan cula atau tidak sengaja, contohnya seperti tidak memberikan obat kepada

$11 \quad$ Ns.Ta'adi, Hukum Kesehatan.,(Jakarta: EGC.2010).Hal 61.

Endang Kusumah Astuti, Hubungan Hukum Antara Dokter dan Pasien Dalam Upaya Pelayanan Medis, (Semarang:2003), Hal,14. 
pasien dikarenakan lupa, atau memberikan obat secara sembarangan sehingga pasien tidak sembuh melainkan penyakitnya bmalah bertambah parah, bahkan sampai meninggal dunia.

Pada golongan yang pertama, perbuatan tersebut dilakukan dengan sengaja dan sadar atau itensional, dolus, tujuan dari tindakan ini sudah terencana kepada akibat yang ditimbulkan nantinya, dan bahkan tidak peduli dengan akibatnya dari perbuatan tersebut. Walaupun demikian tindakan tersebut merupakan tindakan yang bertentangan dengan peraturan hukum yang berlaku. Oleh sebab itu golongan malpraktek lebh sering disebut dengan criminal malpractice. Sedangkan golongan yang kedua perbuatannya lebih sering dikasuskan, sering diartikan sebagai culpa, negligence, ketidak sengajaan, yang tidak diharapkannya akibat yang akan timbul dan sering diartikan sebagai perbuatan yang ceroboh, kurang hati-hati, kurang teliti, sembrono, dan tindakan tersebut tidak peduli terhadap orang lain. ${ }^{13}$

Apabila ditinjau lebih dalam lagi tentang bagaimana cara mendapatkan euthanasia maka euthanasia bisa dibagi lagi menjadi dua macam, antara lain dengan cara sukarela atau euthanasia voluntir dan dengan cara bukan atas permintaa dari pasien atau euthanasia involuntir. Euthanasia voluntir berarti bahwa tindakan euthanasia didapatkan dari permohonan langsung secara sukarela oleh pasien sendiri, sedangkan euthanasia involuntir memiliki artian bahwa euthanasia diperoleh dari permohonan keluarga pasien, yang mana hal ini dikarenakan pasien mengalami koma dalam jangka waktu yang panjang, biaya perawatan medis yang tidak dapat ditanggung oleh keluarga, kasihan kepada pasien karena menahan penderitaan, dan lain sebagainya.

Sampai saat ini di dalam tatanan hukum positif di Indonesia masih belum terdapat regulasi yang mampu menjelaskan secara spesifik dan rinci tentang euthanasia. Di dalam Undang-Undang No. 29 Tahun 2004 tentang Praktik Kedokteran (lex specialis), dan Undang-Undang No. 36 Tahun 2009 tentang Kesehatan tidak ditemukannya pasal yang berkaitan langsung mengatur

\footnotetext{
${ }^{13}$ Machmud,sayahrul,penegakan hukum dan perlindungan bagi dokter yang didugamelakukan medical malpraktek, (Bandung:CV Mandar Maju.2008), Hal.161-162.
} 
tentang euthanasia, namun pengaturan euthanasia masih bisa ditemukan dalam Kitab Undang-Undang Hukum Pidana (KUHP) dan UUD 1945 (lex generalis) meskipun dalam pasal peraturan tersebut tidak mengarah secara langsung pada tindakan atau penerapan euthanasia. Adapun beberapa analisis tentang pasal dalam peraturan tersebut yakni sebagai berikut :

\section{A. Pasal Dalam KUHP yang Berkaitan Dengan Euthanasia}

1. Dalam pasal 344 KUHP mengatur mengenai pembunuhan atas dasar permintaan dari si korban sendiri. Yang diancam sanksi hukum atau hukuman dari pasal ini yaitu orang telah menghilangkan nyawa orang lain atas permohonan dari korban sendiri. Ketentuan pasal 344 KUHP yang mengatur tentang pembunuhan atas permintaan korban itu sendiri. ${ }^{14}$ Pasal 344 KUHP ini sering disebut-sebut sebagai pasal untuk pengaturan euthanasia di Indonesia. Dalam pasal ini terdapat kaitanya dengan jenis euthanasia aktif dan euthanasi avoluntir.

2. Pasal 304 KUHP, merupakan pengaturan hukuman bagi orang yang dengan sengaja meninggalkan orang lain yang seharusnya perlu untuk ditolong, pasal ini lebih condong pada jenis euthanasia pasif.

B. Pasal Dalam UUD 1945 Yang Berkaitan Dengan Euthanasia

1. Pasal 28A yang mengatur mengenai hak untuk hidup bagi seseorang dan hak untuk mempertahankan hidup dan kehidupannya. Keterkaitannya pasal ini dengan euthanasia yaitu bahwa jika psien memiliki keadaan yang sadar maka pasien akan memiliki hak atas kehendaknya sendiri untuk memperlakukan nyawanya tanpa adanya aturan dari orang lain. Sehingga dengan kata lain euthanasia boleh dilakukan melalui euthanasia sukarela karena memilik untuk mati merupakan hak yang dimiliki oleh pasien yang hak tersebut sejajar dengan hak hidup, dan disisi lain euthanasia tidak boleh dilakukan karena melanggar hak untuk mempertahankan hidup dan kehidupannya. Hak hidup akan sulit untuk dilindungi apabila dalam

${ }^{14}$ R.Sugandhi, KUHP dan Penjelasan, 1981, Usaha Nasional, Surabaya, h. 361. 
keadaan yang tidak sadar, sehingga euthanasia dapat dilakukan lewat euthanasia involuntir.

2. Pasal 28G ayat (2) yang mengatur mengenai hak untuk bebas dari penyiksaan dan segala tindakan yang merendahkan derajad dan martabat manusia serta hak untuk menerima suaka politik dari negara lain. Pasal ini menunjukan dukungan untuk menerapkannya euthanasia karena pasien sudah tidak memiliki harapan lagi untuk hidup dan segala upaya medis yang dilakukan akan menambah penderitaan bagi pasien serta ditambah lagi dengan ketidak mampuan keluarga dalam menanggung semua biasya perawatan. Pasal ini memiliki kesesuaian terhadap prinsip euthanasia yaitu tindakan untuk membunuh pasien tanpa memberikan rasa sakit atau penderitaan bagi pasien.

3. Pasal 28I ayat (1), memiliki keterkaitan dengan euthanasia hubungan terkait dengan euthanasia yang mana terdapat hak untuk tidak disiksa dan hak untuk hidup. Terkait dengan analisisnya pasal ini telah diuraikan dalam Pasal 28A dan Pasal 28G ayat 2.

Dalam pengaturan hukum positif di Indonesia, satu-satunya yang digunakan untuk landasan hukum euthanasia adalah KUHP, kususnya pada pasal-pasal di dalam KUHP yang membahas mengenai kejahatan yang menyangkut nyawa manusia. Apabila ditinjau dari sudut pandang KUHP, jenis kejahatan terhadap manusia bertumpu pada subjective element-nya yang dibagi menjadi dua golongan :

1. Tindak kejahatan yang ditargetkan kepada nyawa atau jiwa manusia yang dilakukan dengan sengaja atau dolense misdrijven, hal ini terdapat pada pasal 338 - pasal 350 KUHP.

2. Tindakan kejahatan yang ditargetkan kepada jiwa atau nyawa manusia yang terjadi karena suatu kealpaan atau culponse misdrijven. Hal ini terdapat pada Pasal 359 KUHP. 
Apabila dipandang dari target kejahatan yang berkaitan dengan kepentingan publik yang dilanggar, kejahatan terhadap jiwa manusia di bagi menjadi tiga bagian, yakni :

1. Kejahatan yang memang ditujukan kepada jiwa manusia;

2. Kejahatan yang ditujukan pada jiwa seorang anak yang sedang atau baru dilahirkan;

3. Kejahatan yang ditujukan terhadap jiwa seorang anak yang masih belum dilahirkan.

Kejahatan terhadap jiwa manusia terdiri atas 5 jenis yaitu :

1. Pembunuhan yang dilakukan dengan sengaja atau doodslag,bisa dilihat dalam pasal 338 KUHP;

2. Pembunuhan yang dilakukan dengan cara merencanakannya terlebih dahulu atau moord, dalam Pasal 340 KUHP;

3. Pembunuhan yang apabila dilakukannya dapat memperberat sanksi atau hukuman, (gequalificeerde doodslag), dalam Pasal 339 KUHP;

4. Pembunuhan yang dilakukan karena suatu permohonan secara sungguhsungguh oleh korban, Pasal 344 KUHP;

5. Tindakan seseorang yang dengan sengaja menyarankan, mengupayakan, atau membantu orang lain yang ingin melakukan tindakan bunuh diri, diatur dalam pasal 345 KUHP.

Yang paling mendekati dengan masalah euthanasia tersebut adalah peraturan hukum dalam buku ke-2, Bab XIX pasal 344 KUHP, yang menyatakan bahwa: "barangsiapa merampas nyawa orang lain atas permintaan sendiri yang jelas dinyatakan dengan kesungguhan hati, diancam dengan pidana penjara paling lama dua belas tahun".

Dalam pasal diatas, kalimat "permintaan sendiri yang dinyatakan dengan kesungguhan hati" seharusnya harus memperoleh suatu perhatian, karena dapat dipidana tidaknya seseorang pelaku euthanasia didasarkan pada unsur yang terdapat pada pasal 344 KUHP. Hal ini juga agar pasal tersebut tidak disalah gunakan, jadi harus diteliti benar apakah seseorang telah melakukan pembunuhan atau tidak. Harus dibuktikan adanya unsur-unsur seperti unsur 
permohonan dengan tegas atau unitdrukkelijk, serta unsur kesungguhan atau ernstig, serta harus bisa dibuktikan pula adany alat-alat bukti dan saksi, sebagaimana yang telah diatur dalam pasal 295 HIR $;{ }^{15}$ Upaya bukti yang sesuai dengan undang-undang hanya diakui ;

1. Pengakuan

2. Surat-surat

3. Isyarat-isyarat

4. Kesaksian

Indonesia masih belum mengatur masalah euthanasia secara eksplisit sehingga perlu adanya penemuan hukum, yang akan membimbing penyelesaian masalah dalam pelanggaran hukumnya tindakan euthanasia. Sehingga apabila pasal 344 KUHP diperhatikan, agar orang yang melakukan tindakan euthanasia bisa dinyatakan memenuhi unsur pasal tersebut, maka unsur "permintaan sendiri yang jelas dinyatakan dengan kesungguhan hati, ${ }^{16}$ harus dibuktikan oleh jaksa penuntut umum.

Kasus yang berkaitan dengan euthanasia sampai sekarang belum pernah ada yang dinaikkan ke muka pengadilan di Indonesia, padahal pasal 344 KUHP yang memiliki hubungan dengan euthanasia masih berlaku. Dengan mencantumkan pasal tersebut, pasti telah diduga sebelumnya oleh perundang-undangan bahwa euthansia yang dahulu pernah terjadi di Indonesia tidak menutup kemungkinan akan terjadi lagi kelak di masa yang akan datang, dalam pengertian euthanasia yang aktif. Namun sebenarnya dalam hak pembuktian, pasal 344 KUHP mengalami kesulitan karena adanya kata-kata "atas permintaan sendiri", yang kemudian disusul pula dengan kalimat “yang jelas dinyatakan dengan kesungguhan hati”. Bisa dibayangkan jika orang yang menyatakan dengan kesungguhan hati merupakan orang yang telah meninggal dunia dan otomatis yang bersangkutan tersebut tidak dapat berkomunikasi untuk menyatakan kalimat kesungguhan hatinya.

Apabila dalam pertanggung jawaban pidana bagi seseorang yang melakukan euthanasia dijuruskan kepada asas dalam hukum pidana yakni geen staf zonder

Karjadi M, Reglement Indonesia Yang Dibaharui, (s-1941 no.44), (Plitea Bogor 1975), Hal 84.

Djoko Prakoso, Djaman Andhi Nirwanto, Euthanasia hak asasi manusia dan hukum pidana, (Ghalia Indonesia, Jakarta, 1984Hal.72. 
schuld yang memiliki arti bahwa apabila tidak terjadi kesalahan maka tidak akan dikenai sanksi pidana, maka hal ini lah yang mempersulit pelaku dijatuhi hukuman. Asas yang disebutkan diatas memang tidak tercatat dalam hukum tertulis di Indonesia namun asas tersebut berlaku dalam hukum yang tidak tertulis di Indonesia. ${ }^{17}$. Supaya pertanggungjawaban pidana bisa diminta maka terlebih dahulu harus memenuhi tiga unsur, antara lain $:^{18}$

a. Pelaku dinilai mampu untuk memprtanggungjawabkannya;

b. adanya dolus/culpa atau kesalahan;

c. Tidak Adanya alasan pemaaf.

Apabila ditinjau dari sisi hukum positif Indonesia, euthansia bisa dianggap sebagai tindak pembunuhan. Menurut KUHP, seseorang mampu untuk dipidanakan apabila terbukti dengan sengaja atau tanpa sengaja (kelalaian) menghilangkan nyawa orang lain. Pengaturan pidanayang memiliki kaitan langsung dengan Euthanasia aktif yaitu terdapat pada pasal 344 KUHP.

Pada Euthanasia aktif tidak langsung, dinyatakan dengan seorang tenaga medis atau dokter walaupun memiliki tujuan untuk mengurangi rasa sakit atau penderitaan pasien, namun dokter atau tenaga medis tersebut sangat mengetahui apabila dengan tindakan yang dilakukannya seperti memberikan dosis yang tinggi bisa menyebabkan kematian bagi pasiennya. Tindakan euthanasia bukan merupakan suatu kelalaian,melainkan suatu tindakan yang memang disengaja, mengingat terdapat tiga macam bentuk kesengajaan, diantaranya yaitu : sengaja dengan keinsyafan kemungkinan atau dolus evaluanti, sengaja dengan keinsyafan pasti, dan kesengajaan sebagai maksud.

Dari analisis yang didapat, Euthanasia secara yuridis, memang merupakan suatu tindak pidana pembunuhan, terutama dengan Euthanasia aktif, akan tetapi hukuman tidak diberikan kepada semua orang yang melakukan suatu tindak pidana. Terdapat hal-hal yang menggugurkan, mengurangi, menghapuskan, atau memberatkan hukuman pidana, hal ini

\footnotetext{
17 Moeljatno,ed.rev., Asas-asas Hukum Pidana (Jakarta : PT RINEKA CIPTA,2008), Hal 153

Tongat, dasar-dasar Hukum Pidana Indonesia Dalam Perspektif Pembaharuan (malang : UMM Press, 2009) Hal.225.
} 
diatur dalam KUHP Bab III terutama dalam pasal 48, yang menyatakan : "barang siapa melakukan perbuatan karena pengaruh daya paksa, tidak dipidana”. Dokter pasti akan sangat kasihan apabila pasien yang ditanganinya sudah tidak dapat disembuhnya meskipun telah dilakukan berbagai bantuan alat-alat medis. Hal ini termasuk dalam pengaruh daya paksa secara mental atau psikis. Penafsiran daya paksa termasuk daya paksa secara psikis diatur dalam Pasal 48 KUHP. Namun seiring dengan perkembangan teknologi dalam ilmu kesehatan maka mengenai penafsiran daya paksa psikis memakai penafsiran secara "extension”, yang mana pengaruh daya paksa tersebut bisa ditafsirkan sebagai daya paksa fisik dan psikis.

Kemudian menurut literature Belanda, pada tahun 1987 pengadilan Belanda mulai mempertimbangkan bukan dasar pembenaran melainkan mempertimbangkan dasar menghilangkan culpa. Sehingga apabila terjadi kejahatan yang tidak bisa untuk dibuktikan namun apabila hakim bisa menerima adanya daya paksa atau "overmacht" maka pelaku tidak akan dihukum. Hal tersebut berarti dokter yang telah melakukan tindakan euthanasia terhadap pasien merupakan suatu perbuatan yang dianggap sebagai pelanggran pidana yang seharusnya dibebani pertanggung jawaban pidananya, akan tetapi dokter atau tenaga medis yang bersangkutan mendapatkan keringanan hukuman, bahkan dibebaskan dari hukuman yang didasarkan pada Pasal 48 KUHP secara extension. Atas dasar pemikiran-pemikiran mengenai euthanasia tersebut yang pengaturannya tidak spesifik mengatur tentang euthanasia seharusnya pemerintah memberikan peraturan baru yang lebih jelas mengenai masalah tersebut, baik unsur-unsur yang dapat digolongkan sebagai perbuatan euthanasia maupun sanksi hukumnya apabila perbuatan tersebut dilakukan.

Berdasarkan analisis yang ada dalam penelitian ini bisa dilihat bahwa di Indonesia terdapat peraturan hukum yang berkaitan dengan euthanasia meskipun peraturan tersebut tidak menyinggung secara langsung namun pengaturan mengenani euthanasia secara jelas dan spesifik sampai sekarang ini masih belum ada. Sehingga bisa dinyatakan bahwa euthanasia saat ini di 
Indonesia masih belum mempunyai regulasi atau dasar hukum yang jelas. Akan tetapi apabila melihat pada Pasal 344 KUHP dapat disimpulkan bahwa tindakan yang berakibat membuat orang lain sengsara bahwa menghilangkan nyawa orang lain dengan sengaja sekalipun tindakan tersebut atas permintaan korban tetaplah pelakunya harus diancam dengan hukuman pidana. Sehingga dengan tegas dalam konteks hukum positif Indonesia euthanasia merupakan tindakan pembunuhan yang tidak boleh dilakukan, karena tindakan "mengakhiri hidup seseorang" meskipun hal tersebut atas permohonan orang itu sendiri sekalipun dalam konteks KUHP merupakan perbuatan yang dilarang. Tindkaan tersebut oleh KUHP dimasukkan sebagai tindak pidana yang bagi pelakunya diancam dengan ancaman pidana.

\subsection{Kebijakan Untuk Menerapkan Suntik Mati (Euthanasia) Di Indonesia Dari Sisi Hukum Pidana (KUHP)}

Di Indonesia tidaklah mungkin untuk menerapkan euthanasia karena negara Indonesia sendiri merupakan negara yang berlandaskan atas Ketuhanan Yang Maha Esa dan jika dipandang dari sisi etika kedokteran sekalipun, para tenaga medis dan dokter dilarang untuk melakukan euthanasia hal ini dinyatakan melalui Sumpah Hipokrates. ${ }^{19}$ Sedangkan apabila dipandang dari segi hukum (KUHP) tindakan euthanasia dinyatakan sebagai pembunuhan. ${ }^{20}$ Meskipun di dalam KUHP tidak ada satupun pasal yang menyatakan kata euthanasia tetapi di dalam pasal-pasal tersebut masinh ada beberapa yang berkaitan langsung mengenai penerapan euthanasia, dan dari seluruh pasal yang ada dengan secara tegas menyatakan larangan untuk melakukan kebijakan menerapkan euthanasia di Indonesia. Pada euthanasia aktif, pelaku bisa diancam dengan ancaman pidana dalam Pasal 338 KUHP mengenai tindakan pembunuhan, Pasal 344 KUHP berisikan mengenai pembunuhan yang dilakukan karena permintaan si korban, Pasal 340 KUHP mengenai

19 P.A.F.Lamintang dan Theo Lamintang, 2012, Delik-Delik Khusus Kejatahan Terhadap Nyawa, Tubuh dan Kesehatan, Sinar Grafika, Jakarta, h.80.

20 H. Sutarno, 2014, Hukum Kesehatan Euthanasia, Keadilan dan Hukum Positif Di Indonesia, Setara Press, Malang Jawa Timur, h.73. 
pembunuhan berencana dan Pasal 345 KUHP mengenai bantuan kepada seseorang untuk melakukan bunuh diri. Sedangkan pada euthanasia pasif pelakunya bisa diancam dengan pasal 351 KUHP mengenai pelanggaran kepada orang yang memerlukan bantuan pertolongan, Pasal 306 KUHP mengenai meninggalkan orang lain yang memerlukan pertolongan, dan Pasal 304KUHP.

Dokter atau tenaga medis yang melakukan euthanasia juga bisa diancam dengan ancaman Pasal 57 KUHP, Pasal 56 KUHP,dan Pasal 55 KUHP mengenai ikut turut serta dalam melakukan tindak pidana dikarenakan tindakan medis yang dilakukan pasti dokter dan tenaga medis melakukannya secara bersama-sama. Perbuatan turut serta dalam tindakan pidana bisa dinyatakan apabila didalam terjadinya suatu tindak pidana terdapat penyertaan orang lain atau beberapa orang. ${ }^{21}$

KUHP juga mengatur mengenai hal-hal yang bisa mengurangi atau menghapuskan hukuman bagi tindak pidana, sehingga tidak semua orang yang melakukan tindak pidana memperoleh suatu hukuman pidana, hal tersebut juga berlaku pada tenaga medis atau dokter yang telah melakukan tindkaan euthanasia. Dalam ketentuan Pasal 48 KUHP yang menyatakan bahwa "barangsiapa melakukan perbuatan karena pengaruh daya paksa, tidak dipidana", Kalimat "karena pengaruh daya paksa" tersebut harus diartikan sebagai baik pengaruh lahir, batin, jasmani, maupun rohani, merupakan termasuk dari pengaruh daya paksa. Dengan adanya pengaruh pasal tersebut dapat dikatakan bahwa dokter atau tenaga medis yang melakukan euthanasia dikarenakan adanya pengaruh daya paksa maka dokter atau tenaga medis tersebut mendapatkan keringanan hukuman pidana, tidak dibebani hukuman dan dapat dibebaskan dari ancaman hukuman pidana yang terdapat dalam KUHP.

Berdasarkan dengan ketentuan-ketentuan yang terdapat dalam pasal-pasal yang telah diuraikan sehingga dalam analisis ini memperlihatkan bahwa

Moeljatno, 1985, Delik-Delik Percobaan Delik-Delik Penyertaan, Bina Aksara, Jakarta, hlm. 63. 
kebijakan untuk menerapkan euthanasia di Indonesia ini hanya sangat sedikit meskipun KUHP sendiri telah melarang secara tegas adanya euthanasia di Indonesia. Profesor Separovic, seorang pakar hukum kedokteran, berpendapat bahwa "Contemporary developments have posed a whole series of new problem. One could even say: if medicine is in trouble because of too much change, law is in trouble because of too little change." Berdasarkan pendapat tersebut, meskipun kedepannya terdapat peluang untuk diterapkannya euthanasia di Indonesia akan tetapi lebih baik apabila penerapannya diberikan batasan-batasan tertentu, sehingga kejibakan penerapan euthanasia bisa melindungi kepentingan pasien, keluarga pasien, tenaga medis, maupun dokter, bahkan masyarakat luas.

\section{Kesimpulan}

Berdasarkan pembahasan yang telah dijelaskan sebelumnya, maka bisa ditarik kesimpulan :

1. Meskipun pengaturan mengenai euthanasia secara tidak langsung terdapat dalam peraturan perundang-undangan (lex generalis) yaitu KUHP dan UUD 1945. Namun hukum positif Indonesia sampai sekarang masih belum mengatur tentang euthanasia, sehingga masalah euthanasia belum diatur secara jelas dan spesifik yang mana otomatis euthanasia belum memiliki payung hukum sendiri.

Adapaun larangan yang di sebutkan dalam Kitab Undang-undang Hukum Pidana (KUHP) yang mengatur mengenai tindak pidana terhadap jiwa atau nyawa di golongkan dalam Pasal sebagai berikut :

a) Pembunuhan yang dilakukan atas permintaan atau permohonan dari si korban sendiri ( Pasal 344 KUHP), masuk dalam asas Lex Specialis Derogat Legi Generalis dari :

b) Pembunuhan biasa (Pasal 338 KUHP) yang sampai detik ini pasal tersebut masihlah berlaku. Pasal 344 KUHP merupakan pasal yang dalam bunyinya mendekati tindakan euthanasia 
dengan penggolongan tindakan Euthanasia yang secara aktif dilakukan atas permohonan dengan sungguh-sungguh oleh si korban sendiri, sehingga dalam pasal ini sangat sulit dalam hal mengungkapkan pembuktiannya.

2. Penerapan euthanasia di Indonesia sangatlah tidak mungkin karena menurut hukum positif di Indonesia yaitu KUHP telah memandang euthanasia sebagai tindakan kejahatan pembunuhan yang dilarang dan diancam dengan hukuman pidana bagi pelakunya. Namun apabila memang ada peluang untuk diberlakukannya euthanasia kelak di masa yang akan datang maka perlu adanya pengaturan yang kusus dibuat untuk mengatur euthanasia dan perlu adanya diberikan batasan-batasan dalam melakukan euthanasia. 


\section{DAFTAR PUSTAKA}

\section{Buku}

Achadiat, Chisdiono M., 2007, Dinamika Etika dan Hukum Kedokteran Dalam Tantangan Zaman, Buku Kedokteran EGC, Jakarta

Astuti, Endang Kusumah , Hubungan Hukum Antara Dokter dan Pasien Dalam Upaya Pelayanan Medis, (Semarang:2003)

Indriyanti, Alexandra, 2008, Etika dan Hukum Kesehatan, Pustaka Book Publisher, Yogyakarta

Lamintang, P.A.F., dan Lamintang, Theo, 2012, Delik-Delik Khusus Kejatahan Terhadap Nyawa, Tubuh dan Kesehatan, Sinar Grafika, Jakarta

M, Karjadi, Reglement Indonesia Yang Dibaharui, (s-1941 no.44), (Plitea Bogor 1975)

Moeljatno, 1985, Delik-Delik Percobaan Delik-Delik Penyertaan, Bina Aksara, Jakarta

Moeljatno,ed.rev., Asas-asas Hukum Pidana (Jakarta : PT RINEKA CIPTA,2008)

Notoatmodjo, Soekidjo , 2010, Etika \& Hukum Kesehatan, Rineka Cipta, Jakarta

Ns.Ta'adi, Hukum Kesehatan.,(Jakarta: EGC.2010)

Prakoso, Djoko, Djaman Andhi Nirwanto, Euthanasia hak asasi manusia dan hukum pidana, (Ghalia Indonesia, Jakarta, 1984)

S. Hadi, 2012, Euthanasia Dalam Perspektif Hukum Pidana dan Etika Kedokteran. Progresif

Sayahrul, Machmud, penegakan hukum dan perlindungan bagi dokter yang di duga melakukan medical malpraktek, (Bandung:CV Mandar Maju.2008)

Soekanto, Soerjono dan Mamudji, Sri, 2006, Penelitian Hukum Normatif Suatu Tinjauan Singkat, PT. Raja Grafindo Persada, Jakarta

Sugandhi, R, KUHP dan Penjelasan, 1981, Usaha Nasional, Surabaya

Sutarno, H, 2014, Hukum Kesehatan Euthanasia, Keadilan dan Hukum Positif Di Indonesia, Setara Press, Malang Jawa Timur 
Tongat, dasar-dasar Hukum Pidana Indonesia Dalam Perspektif Pembaharuan (malang : UMM Press, 2009)

\section{Jurnal}

Natangsa, Surbakti, Euthanasia dalam Hukum Indonesia, Suatu Telaah Kefilsafatan Terhadap Eksistensi dalam Konteks Masyarakat Indonesia Modern, Dalam Jurnal Hukum, Vol. I No. 1 Maret 1998, FH. UMS

Supriati, Tjahjaningtyas, 1986,'Euthanasia Ditinjau dari Hukum Pidana Yang Berlaku di Indonesia”, Milik Perpustakaan Universitas Airlangga Surabaya.

Suwarto, "euthanasia dan perkembangannya dalam KUHP" "Pro Justicia" Volume 27 No 2, Oktober 2009

Tjandra Sridjaja, Pradjonggo, Suntik Mati (Euthanasia) Ditinjau Dari Aspek Hukum Pidana Dan Hak Asasi Manusia Di Indonesia, Jurnal Ilmiah Pendidikan Pancasila Dan Kewarganegaraan, Th. 1, Nomor 1, Juni 2016

Yudaningsih, Lilik Purwastuti. 2015, Tinjauan Yuridis Euthanasia Dilihat Dari Aspek Hukum Pidana, Jurnal Ilmu Hukum Universitas Jambi

\section{Perundang-Undangan}

Kitab Undang-Undang Hukum Pidana (KUHP)

UUD 1945

Undang-Undang No. 29 Tahun 2004 tentang Praktik Kedokteran Undang-Undang No. 36 Tahun 2009 tentang Kesehatan

\section{Situs Internet}

Anonim, "Euthanasia

Definitions", URL

http://www.euthanasia.com/definitions.html. Diakses pada 8 Agustus 2019 